Article

\title{
The Elements of Effective Program Design: A Two-Level Analysis
}

Michael Howlett ${ }^{1,2}$, Ishani Mukherjee ${ }^{2}$ and Jeremy Rayner ${ }^{3}$

${ }^{1}$ Department of Political Science, Simon Fraser University, Burnaby, BC, Canada; E-Mail: howlett@sfu.ca;

Tel.:+1-778-782-3082 Fax: +1-778-782-4293

${ }^{2}$ Lee Kuan Yew School of Public Policy, National University of Singapore, Singapore; E-Mail: im49@cornell.edu (I.M.)

${ }^{3}$ Johnson-Shoyama Graduate School of Public Policy, University of Saskatchewan, Saskatoon, Saskatchewan, Canada;

E-Mail: jeremy.rayner@usask.ca

\section{How to Cite this Article}

Howlett, M., Mukherjee, I., \& Rayner, J. (2014). The Elements of Effective Program Design: A Two-Level Analysis.

Politics and Governance, 2(2), 1-12.

\section{Copyrights}

(C) 2014 by the authors; licensee Cogitatio (Lisbon, Portugal). This article is licensed under a Creative Commons Attribution 4.0 International License (CC BY).

\section{Published by:}

\section{COGITATIO}

www.cogitatiopress.com

\section{About the Journal}

Politics and Governance is an innovative new offering to the world of online publishing in the Political Sciences. An internationally peer-reviewed open access journal, Politics and Governance publishes significant, cutting-edge and multidisciplinary research drawn from all areas of Political Science.

www.cogitatiopress.com/politicsandgovernance

\section{Editors-in-Chief}

Professor Andrej J. Zwitter, Faculty of Law, University of Groningen, The Netherlands

Professor Amelia Hadfield, Department of Psychology, Politics and Sociology, Canterbury Christ Church University, UK

\section{Managing Editor}

Mr. António Vieira, Politics and Governance, Cogitatio Press, Portugal 
Article

\title{
The Elements of Effective Program Design: A Two-Level Analysis
}

\author{
Michael Howlett ${ }^{1,2, *}$, Ishani Mukherjee ${ }^{2}$ and Jeremy Rayner ${ }^{3}$ \\ ${ }^{1}$ Department of Political Science, Simon Fraser University, Burnaby, BC, Canada; E-Mail: howlett@sfu.ca; \\ Tel.:+1-778-782-3082; Fax: +1-778-782-4293 \\ ${ }^{2}$ Lee Kuan Yew School of Public Policy, National University of Singapore, Singapore; E-Mail: im49@cornell.edu (I.M.) \\ ${ }^{3}$ Johnson-Shoyama Graduate School of Public Policy, University of Saskatchewan, Saskatoon, Saskatchewan, Canada; \\ E-Mail: jeremy.rayner@usask.ca
}

* Corresponding author

Submitted: 8 March 2014 | In Revised Form: 26 April 2014 | Accepted: 6 May 2014 | Published: 9 June 2014

\begin{abstract}
Policy and program design is a major theme of contemporary policy research, aimed at improving the understanding of how the processes, methods and tools of policy-making are employed to better formulate effective policies and programs, and to understand the reasons why such designs are not forthcoming. However while many efforts have been made to evaluate policy design, less work has focused on program designs. This article sets out to fill this gap in knowledge of design practices in policy-making. It outlines the nature of the study of policy design with a particular focus on the nature of programs and the lessons derived from empirical experience regarding the conditions that enhance program effectiveness.
\end{abstract}

\section{Keywords}

policy design; program design; public policy

\section{Issue}

This article is part of a regular issue of Politics and Governance, edited by Professor Andrej J. Zwitter (University of Groningen, The Netherlands) and Professor Amelia Hadfield (Canterbury Christ Church University, UK).

(C) 2014 by the authors; licensee Cogitatio (Lisbon, Portugal). This article is licensed under a Creative Commons Attribution 4.0 International License (CC BY).

\section{Introduction: Understanding the Relationship between Policy Design and Program Design}

Program design is part of a general effort on the part of governments to systematically develop and implement efficient and effective policies (Bobrow \& Dryzek, 1987; Bobrow, 2006). Policy design is typically done through the application of knowledge about policy means gained from experience and reason to the development and adoption of courses of action expected to attain desired goals or aims (Howlett \& Rayner, 2013).

Not all policies and programs are designed in this sense, and some programs and policies emerge from processes such as patronage, clientelism, bargaining or log-rolling in which the quality of the causal or logical linkages between different components of a program may be less significant than other values, such as politi- cal or electoral gain or loss avoidance. However many do result from more deliberate efforts on the part of governments to forge a clear relationship between policy goals and the means used to address them (Dorst, 2011).

Policy design is thus a major theme of contemporary policy research, aimed at improving the understanding of how the processes, methods and tools of policy-making are employed to better formulate effective policies and programs, or to understand the reasons why such designs are not forthcoming (Howlett, Mukherjee, \& Woo, 2014). However, while many efforts have been made to evaluate policy design (Howlett \& Lejano, 2013), less work has focused on program design (Barnett and Shore 2009). This article sets out to fill this gap in our knowledge of design practices in government. It outlines the nature of the study of policy design with a particular focus on the design of programs and 
the lessons derived from empirical experience regarding the conditions that enhance program effectiveness.

In doing so, the article is organized as follows. The main segment distills and presents existing knowledge about effective practice in program design. By illustrating programs as an intermediary level of policymaking situated between broad policy goals on one hand and specific settings of policy instrument combinations on the other, this section provides a brief elaboration of the evolution of modern principles defining effective design. Research findings and evidence about effective practice are then used to identify the various design needs that must be addressed for effective policy programs to emerge from a design process. In particular, this section derives lessons about maximizing complementarity between policy components, enhancing the goodness of fit between program elements and governance contexts and understanding the design constraints that limit the degrees of freedom available for program design.

\section{The Components of Public Policy and Effective Program Design}

In one sense of the term, program 'design' is a verb describing the manner in which the policy formulation process creates a program that is sensitive to contextspecific constraints. However, "design" is also a noun describing the resulting policy product that emerges from the formulation process.

What is it that is 'designed' in program design? Here it is important to recognize (see Table 1) that policies are composed of several elements, distinguishing between abstract or theoretical/conceptual goals, specific program content or objectives and operational settings or calibrations (Hall, 1993; Howlett \& Cashore,
2007; Howlett \& Cashore, 2009). A policy design consists of specific types of policy tools or instruments that are bundled or combined in a principled manner into policy 'portfolios' or 'packages' in an effort to attain often multiple policy goals and aims. Programs are one component or level at which such designs emerge.

Each of these component elements is conceived and created by policy-makers in the course of the policy-making process. Some components of a policy are very abstract and exist at the level of general ideas and concepts about policy goals and appropriate types of policy tools which can be used to achieve them. Others are more concrete and specific and directly affect administrative practice on the ground. Programs exist between these two levels, operationalizing abstract goals and means and encompassing specific on-the-ground measures and instrument calibrations.

Seen in this larger context, a policy 'program' is a distinctive part of a policy portfolio comprised of a combination of policy instruments or program mechanisms, arranged to meet operationalizable policy objectives (Howlett, 2011). Policy programs thus occupy a central position translating high-level goals and instrument logics and aspirations into operationalizable measures which can be implemented on the ground in specific policy circumstances (Guy et al., 2006).

That is, as presented in Table 1, the elements occupying these different levels of policy design are related to one another in a nested fashion. Program design thus requires an integrated view of different levels of policy goals and means in order to ensure that the elements which compose a program reinforce rather than contradict or conflict with either general, abstract principles or specific on-the-ground measures and mechanisms (Meijers \& Stead, 2004; Briassoulis, 2005).

Table 1. Components of a Policy Mix and the Position of Policy Programs Therein.

\begin{tabular}{|c|c|c|c|}
\hline & Policy Content & & \\
\hline $\begin{array}{l}\text { Policy } \\
\text { Content }\end{array}$ & $\begin{array}{l}\text { High Level Abstraction } \\
\text { (Policy-Level) }\end{array}$ & $\begin{array}{l}\text { Operationalization (Program- } \\
\text { Level) }\end{array}$ & $\begin{array}{l}\text { On-the-Ground Specification } \\
\text { (Measures-Level) }\end{array}$ \\
\hline $\begin{array}{l}\text { Policy } \\
\text { Ends or } \\
\text { Aims }\end{array}$ & $\begin{array}{l}\text { POLICY GOALS } \\
\text { What General Types of } \\
\text { Ideas Govern Policy De- } \\
\text { velopment? } \\
\text { (e.g. environmental pro- } \\
\text { tection, economic devel- } \\
\text { opment) }\end{array}$ & $\begin{array}{l}\text { PROGRAM OBJECTIVES } \\
\text { What Does Policy Formally Aim } \\
\text { to Address? } \\
\text { (e.g. saving wilderness or species } \\
\text { habitat, increasing harvesting } \\
\text { levels to create processing jobs) }\end{array}$ & $\begin{array}{l}\text { OPERATIONAL SETTINGS } \\
\text { What are the Specific } \\
\text { On-the-ground Requirements of } \\
\text { Policy } \\
\text { (e.g. considerations about sustaina- } \\
\text { ble levels of harvesting) }\end{array}$ \\
\hline $\begin{array}{l}\text { Policy } \\
\text { Means or } \\
\text { Tools }\end{array}$ & $\begin{array}{l}\text { INSTRUMENT LOGIC } \\
\text { What General Norms } \\
\text { Guide Implementation } \\
\text { Preferences? } \\
\text { (e.g. preferences for the } \\
\text { use of coercive instru- } \\
\text { ments, or moral suasion) }\end{array}$ & $\begin{array}{l}\text { PROGRAM MECHANISMS } \\
\text { What Specific Types of } \\
\text { Instruments are Utilized? } \\
\text { (e.g. the use of different tools } \\
\text { such as tax incentives, or public } \\
\text { enterprises) }\end{array}$ & $\begin{array}{l}\text { TOOL CALIBRATIONS } \\
\text { What are the Specific Ways in } \\
\text { Which the Instrument is used? } \\
\text { (e.g. designations of higher levels of } \\
\text { subsidies, the use of mandatory vs } \\
\text { voluntary regulatory guidelines or } \\
\text { standards) }\end{array}$ \\
\hline
\end{tabular}

Source: Howlett \& Rayner, 2013, p. 8. 


\subsection{An Example: U.S. Conservation Policy and the Conservation Reserve Program (CRP) Therein}

Exactly how different abstract and concrete policy elements should be combined to create effective and efficient programs is the central question and problem facing program designers. To illustrate the above conceptualization further, examples from United States land conservation policy and a constituent Payments for Ecosystem Services (PES) program are presented here. The U.S. government through the Conservation Reserve Program (CRP) currently makes payments of about US\$1.8 billion per year through contracts with almost 700,000 farmers and landowners, who agree to withhold agricultural activity on 26.8 million acres of ecologically sensitive land (USDA, 2013). Instead of farming on sensitive areas of their land, these farmers agree to "remove environmentally sensitive land from agricultural production and plant grassers or trees that will improve water quality and improve waterfowl and wildlife habitat" (USDA, 2013). The largest PES program globally is the United States Conservation Reserve Program (CRP).

In implementing the CRP, the high-level abstraction of the policy-level (Table 2) includes the general policy goals and instrument logics which inform the general contours and content of both policy and program design, as well as mechanism, design. The main goal of overall land conservation policy in the U.S. in this sense recognizes that most of the benefits obtained from ecosystem services, such as water quality, carbon sequestration, climate regulation, recreation, nutrient cycling, erosion prevention and soil creation occur as positive externalities or benefits that are unaccounted for by the economy. In addition, these services emerge out of the preservation of natural systems and their conservation is often conflicting with extractive economic activities, such as intensive agriculture. In this example the conception of ecosystem services and their provision is a main general idea that governs policy development. The idea that payments can be made for the loss of ecosystem services is the instrument logic, or the body of norms that guide implementation preferences at the policy-level. This embodies the understanding that that since the economy will always undermine the provision of these non-market positive externalities, government mandated compensation can be used to link the interests of landowners and external actors to the conservation of ecosystems (Wunder, 2007).

Supporting operationalization at the program-level is the formulation of policy objectives and the related mechanisms that are used to meet them within this general policy goal and instrument logic (Table 2). The formal objective of the CRP program is the conservation of a specific set of ecologically vital land areas that ameliorate water quality, mitigate soil erosion and diminish the depletion of wildlife habitat (USDA, 2013).

Table 2. Components of the U.S. Conservation Reserve Program.

\begin{tabular}{|c|c|c|c|}
\hline & \multicolumn{3}{|l|}{ Policy Content } \\
\hline & $\begin{array}{l}\text { High Level Abstraction (Policy- } \\
\text { Level) }\end{array}$ & $\begin{array}{l}\text { Operationalization (Program- } \\
\text { Level) }\end{array}$ & $\begin{array}{l}\text { On-the-Ground Specification } \\
\text { (Measures-Level) }\end{array}$ \\
\hline Policy & GOALS & OBJECTIVES & SETTINGS \\
\hline $\begin{array}{l}\text { Ends or } \\
\text { Aims }\end{array}$ & $\begin{array}{l}\text { What General Types of Ideas } \\
\text { Govern Policy Development? } \\
\text { Ecosystem services, or the bene- } \\
\text { fits that people derive from natu- } \\
\text { ral systems, need to be secured } \\
\text { since they are not accounted for } \\
\text { and therefore undercut by the } \\
\text { economy. }\end{array}$ & $\begin{array}{l}\text { What Does Policy Formally Aim } \\
\text { to Address? } \\
\text { Conserving, re-establishing valu- } \\
\text { able land cover to help improve } \\
\text { water quality, prevent soil ero- } \\
\text { sion and reduce loss of wildlife } \\
\text { habitat. }\end{array}$ & $\begin{array}{l}\text { What are the Specific } \\
\text { On-the-ground Requirements of } \\
\text { Policy } \\
\text { (e.g). Considerations about which } \\
\text { land area types are a priority for } \\
\text { the program, mechanisms for } \\
\text { setting up payment-transfers } \\
\text { through local agencies. }\end{array}$ \\
\hline Policy & INSTRUMENT LOGIC & MECHANISMS & CALIBRATIONS \\
\hline $\begin{array}{l}\text { Means } \\
\text { or }\end{array}$ & $\begin{array}{l}\text { What General Norms Guide Im- } \\
\text { plementation Preferences? }\end{array}$ & $\begin{array}{l}\text { What Specific Types of } \\
\text { Instruments are Utilized? }\end{array}$ & $\begin{array}{l}\text { What are the Specific Ways in } \\
\text { Which the Instrument is used? }\end{array}$ \\
\hline Tools & $\begin{array}{l}\text { Payments for Ecosystem Services } \\
\text { or the logic that the use of finan- } \\
\text { cial instruments or creating mar- } \\
\text { kets are effective ways to secure } \\
\text { ecosystem services by transform- } \\
\text { ing the conservation of positive } \\
\text { externalities into financial bene- } \\
\text { fits for local providers. }\end{array}$ & $\begin{array}{l}\text { Conditional cash transfers or } \\
\text { payment contracts with land- } \\
\text { owners to conserve instead of } \\
\text { develop ecologically sensitive ar- } \\
\text { eas. }\end{array}$ & $\begin{array}{l}\text { (e.g) Rate of yearly payments, } \\
\text { length (years) that contracts are } \\
\text { valid, enrollment eligibility, , ad- } \\
\text { justing for ecological sensitivity } \\
\text { land over time. }\end{array}$ \\
\hline
\end{tabular}


The mechanisms or the specific types of instruments adopted by the CRP program take the form of conditional cash transfers or payment contracts with landowners to conserve ecologically sensitive acres on their land. Supplementary instruments in the 'package' symbolized by the CRP, include cost-sharing schemes by the implementing agency, in this case the Farm Service Agency (FSA) active in each state. Specific on-theground measures then involve adjustments to policy settings and the calibration of policy tools and tool mixes. In the CRP example (Table 2), the specific policy settings are the requirements related to the classification of land-use, land-cover types (such as wetland or riparian buffer zones or wildlife corridors) and the conservation priorities assigned to each, as well as other components such as how land parcels should be valued as well as choosing and setting up necessary payment arrangements through local land agencies. These onthe-ground settings then relate to the specific calibrations of the instruments contained within the CRP, including such features as the regular adjustments and fine-tuning of payment amounts, contract lengths and eligibility criteria based on economic indicators such as national budgets and inflation.

\section{Policy Programs and Policy Design: A Short History}

The main emphasis of recent policy design research has been on the importance of utilizing the full range of policy components available when putting together a program while avoiding unnecessary duplication and conflicts between program components (Gunningham, Grabosky, \& Sinclair, 1998). Contemporary design thinking additionally recognizes the limitations placed on the adoption of program elements by their situation within an overall policy framework, and the need to match the more technical aspects of government financial and human resource availability and capabilities with existing levels of administrative capacity, budgeting and personnel resources, and other similar requirements of policy implementation.

Over time, researchers have articulated a series of principles to help promote better and more effective policy designs. Maxims for effective design developed in the late 1950s, for example, focused on efficiency concerns and urged the parsimonious use of policy tools. An oft-cited rule proposed by the Nobel Prize winning economist Jan Tinbergen in 1952, for instance, suggested that optimal designs emerged when the number of policy tools was directly proportional to the number of goals a policy was expected to achieve (Tinbergen, 1952; del Rio \& Howlett, 2013). This research obtained a dynamic component in the 1970s when scholars began to deal with questions about the proper 'sequencing' or phasing of policy efforts over time
(Taeihagh, 2013). Studies by Doern and his colleagues, for example, promoted the idea that effective program design involved the initial use of the least-coercive instrument expected to be able to address a problem, with governments moving up 'the scale of coercion' to use more intrusive instruments to achieve their policy goals only in response to the failure of less coercive tools to achieve policy goals and objectives (Doern \& Phidd, 1983; Doern \& Wilson, 1974; Woodside, 1986).

In recent years program design thinking has refined and expanded upon these insights. The articulation of principles of what constitutes a "good" design has evolved from thinking about relatively simple 'one goal-one instrument' situations to address issues related to the use of more complex policy mixes or bundles of tools that aim to unite multiple interconnected goals and the means to achieve them across multiple levels of government (Howlett \& del Rio, 2014). Daugbjerg and Sonderskov (2012) in their review of organic food policies in Denmark, Sweden, UK and the US, for example, noted that "significant growth in green markets is most likely to result where a combination of policy instruments directed at the supply side and demand side of the market is simultaneously implemented" (p. 415).

In pursuing research into the question of how to best formulate deliberate packaging of policy elements into programs targeted to meet certain policy goals, scholars and practitioners have focused on 'balancing' two aspects of the policy relationships set out in Table 1. These are the 'policy-program' linkages and the 'program-measures' ones highlighted in that table (see Table 3).

Dealing with 'policy-program linkages' involves the need to set program objectives and mechanisms that fit overall, broader policy goals and instrument logics. In the U.S. Conservation Reserve Program case set out above, for example, the policy-program linkages establish the program's objective of preventing soil erosion, improving water quality and preserving wildlife habitat as needed to uphold the overall policy aim of conserving ecosystem services through the use of financial incentives encouraging conservation. 'Program-measure linkages', on the other hand, establish the need to fit program mechanisms to specific on-the-ground policy measures. In the CRP case, this involves ensuring payment agreements between the Government and landowners reflect the priorities given to the conservation of different land types and to monitor how successfully these agreements are implemented in practice through the fair assessment of yearly payments and contract lengths, for example.

Principles and practices of program design related to these two general areas of concern are set out in more detail below. 
Table 3. Program Level "Needs" for Effective Design.

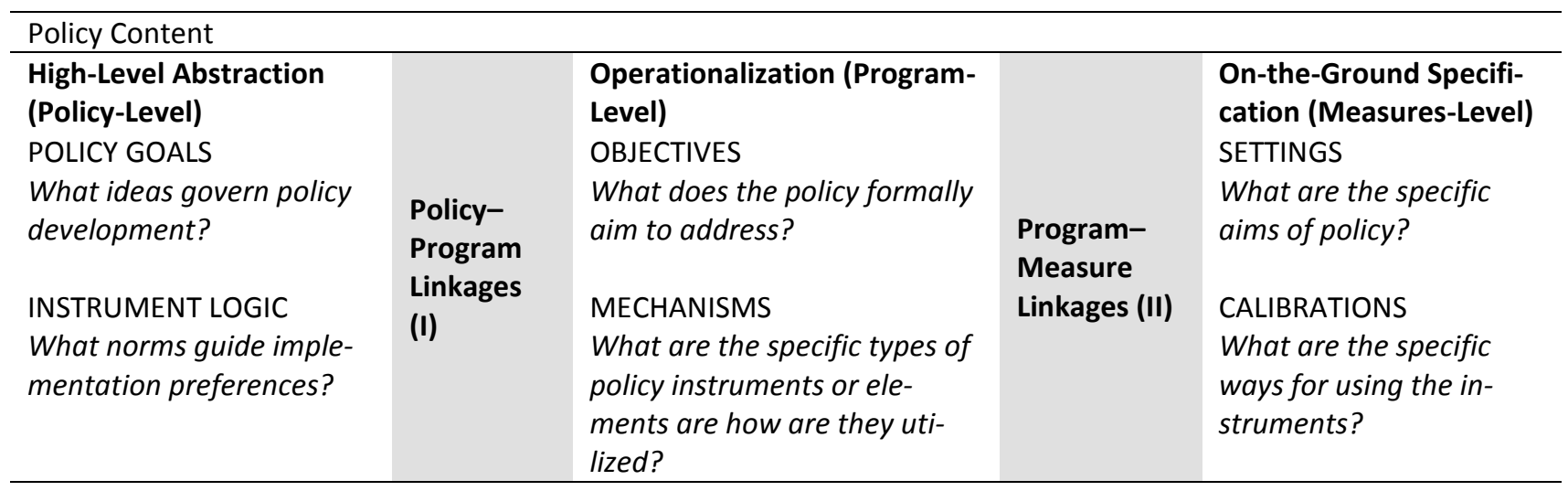

\section{Principles for Designing Programs: Policy-Program Linkages (I)}

Studies over the past two decades exploring 'smart regulation' in environment policy and in land use management and planning (Gunningham, Grabosky, \& Sinclair, 1998; Rayner \& Howlett, 2009; Ben-Zadok, 2013) have helped underline the significance and effectiveness of program designs that are compatible with existing governance conditions. Borne out of such studies, several principles have emerged to illustrate and instruct how effective policy-program linkages can be designed.

\subsection{Goodness of Fit: Matching Governance Mode and Policy Capacities}

One such principle is the notion of "goodness of fit". That is, as set out above, effective program designs need to reflect and respond to the specific contextual features of the particular policy sector(s) that they involve. How well a program is able to align itself with context-dependent policy realities determines its "goodness of fit" within an existing governance structure and the various other policy regime elements at the international, national, sub-national and local levels of governments within which it is embedded (Howlett, 2011). Different governance styles and preferences at each level require and influence specific types of state and social actor capacities and capabilities and these limitations and strengths inform judgments about the feasibility of program-level options and alternative arrangements of objectives and mechanisms.

Questions of goodness of fit thus connect program design with a central concern of policy analysis, the ex ante feasibility of instruments and their settings in a larger political context (Meltsner, 1972; Majone, 1989). While it is true that program designs that might appear infeasible in terms of goodness of fit can subsequently turn out to be effective (or else policy innovation would be an even more rare occurrence than it actually is), judgments about feasibility are an established feature of policy advice. For example, studies of governance modes and 'policy styles', mostly stemming from Europe and North America throughout the 1980s1990s (see for example, Richardson, Gustafsson, \& Jordan, 1982; Freeman, 1985; Kiss \& Neij, 2011) described several common patterns of governance arrangements that need to be reflected in policy program designs in order for these designs to be considered feasible and thus improve their chances of adoption. While many possible permutations and combinations of such governance arrangements exist, recent policy and administrative studies have focused on four basic types or "governance modes" found in many jurisdictions (see Table 4).

Each mode of governance listed in Table 1 broadly displays a different focus, form of control, aim and preferred service delivery mechanism and procedural policy orientation which affect and inform design practices and contents. Government actions through legal and network governance, for example, can change many aspects of policy behaviour but do so indirectly through the alteration of the relationships existing between different kinds of social actors. This is unlike corporate and market governance, each of which involves a preference for more overt state direction. The program elements of policy designs must incorporate knowledge about these particular characteristics and preferences if they are to be considered feasible or appropriate.

Claims and counterclaims about feasibility have a strongly rhetorical character and disputes over these claims is a characteristic feature of many design processes. A key insight of contemporary research into the design of programs that successfully address policy aims is that designing involves thinking about and coordinating aspects of policy arrangements which occur over multiple levels of policy activity (Howlett \& del Rio, 2014). Activities at all of these levels, along with the details of implementation, must be coordinated and integrated if optimal results are to be attained. 
Table 4. Different Governance Modes and Policy Capacity Considerations.

\begin{tabular}{|c|c|c|c|c|c|}
\hline $\begin{array}{l}\text { Mode of } \\
\text { Governance }\end{array}$ & $\begin{array}{l}\text { Central Focus of } \\
\text { Governance } \\
\text { Activity }\end{array}$ & $\begin{array}{l}\text { Form of State } \\
\text { Control of } \\
\text { Governance } \\
\text { Relationships }\end{array}$ & $\begin{array}{l}\text { Overall } \\
\text { Governance } \\
\text { Aim }\end{array}$ & $\begin{array}{l}\text { Prime Service } \\
\text { Delivery } \\
\text { Mechanism }\end{array}$ & $\begin{array}{l}\text { Key Procedural } \\
\text { Tool for Policy } \\
\text { Implementation }\end{array}$ \\
\hline $\begin{array}{l}\text { Legal } \\
\text { Governance }\end{array}$ & $\begin{array}{l}\text { Legality - } \\
\text { Promotion of law } \\
\text { and order in social } \\
\text { relationships }\end{array}$ & $\begin{array}{l}\text { Legislation, Law } \\
\text { and Rules }\end{array}$ & $\begin{array}{l}\text { Legitimacy - } \\
\text { Voluntary } \\
\text { Compliance }\end{array}$ & $\begin{array}{l}\text { Rights - Property, } \\
\text { Civil, Human }\end{array}$ & $\begin{array}{l}\text { Courts and } \\
\text { Litigation }\end{array}$ \\
\hline $\begin{array}{l}\text { Corporate } \\
\text { Governance }\end{array}$ & $\begin{array}{l}\text { Management - of } \\
\text { Major Organized } \\
\text { Social Actors }\end{array}$ & Plans & $\begin{array}{l}\text { Controlled and } \\
\text { Balanced Rates of } \\
\text { Socio-economic } \\
\text { Development }\end{array}$ & $\begin{array}{l}\text { Targets - } \\
\text { Operational } \\
\text { Objectives }\end{array}$ & $\begin{array}{l}\text { Specialized and } \\
\text { Privileged Advisory } \\
\text { Committees }\end{array}$ \\
\hline $\begin{array}{l}\text { Market } \\
\text { Governance }\end{array}$ & $\begin{array}{l}\text { Competition - } \\
\text { Promotion of Small } \\
\text { and Medium sized } \\
\text { Enterprises }\end{array}$ & $\begin{array}{l}\text { Contracts and } \\
\text { Regulations }\end{array}$ & $\begin{array}{l}\text { Resource/Cost } \\
\text { Efficiency and } \\
\text { Control }\end{array}$ & $\begin{array}{l}\text { Prices - Controlling } \\
\text { for Externalities, } \\
\text { Supply and } \\
\text { Demand }\end{array}$ & $\begin{array}{l}\text { Regulatory Boards, } \\
\text { Tribunals and } \\
\text { Commissions }\end{array}$ \\
\hline $\begin{array}{l}\text { Network } \\
\text { Governance }\end{array}$ & $\begin{array}{l}\text { Promotion of Inter- } \\
\text { actor } \\
\text { organizational } \\
\text { Activity }\end{array}$ & Collaboration & $\begin{array}{l}\text { Co-Optation of } \\
\text { Dissent and Self- } \\
\text { Organization of } \\
\text { Social Actors }\end{array}$ & $\begin{array}{l}\text { Networks of } \\
\text { Governmental, } \\
\text { and Non- } \\
\text { Government } \\
\text { Organizations }\end{array}$ & $\begin{array}{l}\text { Subsides and } \\
\text { Expenditures on } \\
\text { Network Brokerage } \\
\text { Activities }\end{array}$ \\
\hline
\end{tabular}

Source: Considine \& Lewis, 2003.

Not surprisingly, while the level of concern for matching governance context and program elements is always high it becomes even more complex and charged when the policy or program area extends beyond the jurisdiction of a single level of government to incorporate such multi-level governance (MLG) considerations.

This is well illustrated by the case of environmental policy-making and program design across the nations of the European Union (EU) after 1960. In many of these countries a previous penchant for the use of regulatory and command-and-control instruments aligned with more active forms of state governance have given way to more market-based tools as governance arrangements in general at the EU level have shifted in this direction (Jordan, 2005). However within this general tendency a great variety now exists today in the EU with respect to the type of market or economicbased tools preferred in each individual member country (Jordan, 2005). For example, evaluations of environmental policy program arrangements have highlighted that moves towards planning and 'steering' in such contexts involve indirect co-ordination of key actors by governments, requiring "a high level of government policy capacity to identify and utilize specific policy tools capable of successful moving policy targets in a required direction" (Howlett \& Rayner, 2013; Arts, Leroy, \& van Tatenhove, 2006). Nordic nations which have corporatist governance conditions and fiscal and other capacities that allow a better fit with 'secondgeneration' market based instruments (MBIs) such as emissions trading, whereas less-wealthy European countries "are still employing first-generation MBIs such as simple effluent taxes and user charges" (Jordan, 2005, p. 486). "Goodness of fit" involving judgments about the feasibility of program elements within overall governance arrangements thus plays a key role in designing effective programs both in state-level jurisdictions and at the EU level. Better program designs ensure programs content and pre-requisite conditions match governance contexts.

\subsection{Degrees of Freedom: The Impact of Layering}

However, as the EU case also shows, even with a high capacity for action, not all possible program options may be available to designers. A second design consideration is thus one directed at the relative ease or difficulty with which policy designers can change the status quo given the embeddedness or tractability of past policy and program choices. Conceptually, if unlimited 'degrees of freedom' are available to policy-makers then any combination of policy tools and program objectives might be possible in any circumstance (Howlett \& Rayner, 2013). However, practical experience with large-scale institutional changes has suggested that the existence of this amount of 'elbow-room' for mixing or designing policy elements is uncommon and many program design contexts are, rather, heavily 'path dependent' (Pierson, 2000; David, 2005).

Other than in completely new areas of policy, or in cases where political punctuations have led to a full rethink or overhaul of old policy, most policy and program designers typically work with restricted 'degrees of freedom' or within constraints created by layers of 
already existing policy mixes that cannot be easily altered (Thelen, 2003; van der Heijden, 2011). As corroborated by evidence from studies of the evolution of sectors such as welfare policy and natural resources over long periods of time, many existing policy combinations developed incrementally through a gradual historical process of the piecemeal addition or alteration of elements of policies and programmes (Lindblom, 1959; Howlett \& Migone, 2011). Such mixes may be 'disorganized (Bode, 2006) and cry out for rationalization but are nevertheless difficult to change (Hacker, 2005).

Many sustainability strategies, for example, have suffered from incremental adjustment through layering, or the process whereby new elements are simply added to an existing regime without abandoning previous ones (van der Heijden, 2011; Thelen, 2003). Many efforts at the integration of various resource management regimes, for instance, have failed when powerful interests are able to keep favourable goals, instruments and settings, such as unsustainable fishing or timber cutting quotas that support an industry, and limit the impact of new policy initiatives (Rayner \& Howlett, 2009).

The temporality of these policy development processes place constraints on contemporary designers and like the governance contexts cited above, is a key issue in program design. The deadweight of the past necessitates the examination of the pre-existing historical organization of policy components in order to gauge the feasibility of moving specific design options forward (Christensen, Laegreid, \& Wise, 2002). Effective program design must take these temporal contexts into account in proposing new remedies; often leading to an emphasis on "patching" policy rather than 'repackaging' it altogether (Howlett, Mukherjee, \& Woo, 2014; Howlett \& Rayner, 2013).

\section{Principles for Designing Programs: Program- Measure Linkages (II)}

Effective program design must address both policyprogram level and the program-measure level of interactions among program elements (see Table 3). On the ground program elements often involve aspects of what Elinor Ostrom (2011; Ostrom \& Basurto, 2011) designated as the 'rules' of institutional design and analysis. These include designing program components which cover aspects such as:

- Boundary rules: Who is covered by this program? Is participation and coverage automatic or is a new participant allowed to join paying some kind of entry charge, fee or tax?

- Position rules: How does an actor move from being a target of a program activities to one with a specialized task in program implementation, such as the chair of a management committee?
- Scope rules: What activities are covered by the program?

- Choice rules: What choices do various types of actors have in relation to the actions they can or are expected to take in the program?

- Aggregation rules: What understandings exist concerning how actors can affect or alter the rules affecting their actions. Do certain actions require prior permission from, or agreement of, others?

- Information rules: What information about the program or relevant to it is held secret, and what information is made public?

- Payoff rules: How large are the sanctions that can be imposed for breaking any of the rules identified above? How is conformance to rules monitored? Who is responsible for sanctioning nonconformers? How reliably are sanctions imposed? Are any positive rewards offered? (Ostrom, 2011, pp. 2021).

Achieving effectiveness with respect to deploying program mechanisms at this level relies upon ensuring mechanisms, calibrations, objectives and settings display 'coherence', 'consistency' and 'congruence' with each other (Howlett \& Rayner, 2007). Within this general rubric, however, several specific principles of effective program design also exist. Two of thesemaximizing complementary effects and the need to balance the attainment of equity, efficiency, economy and environmental concerns-are discussed below.

\subsection{Maximizing Complementary Effects}

Policy design studies have pointed out that many existing policy mixes are not comprised exclusively of tools or elements that complement and enhance each other (Grabosky, 1995). Grabosky (1995) and other scholars investigating policy combinations throughout the latter half of the 1990s, for example, noted that policy packages and programs combining command-and-control regulation with modes of voluntary compliance can be internally contradictory and should be avoided in effective design.

One key principle at this level of design analysis and practice, therefore, is to maximize complementary relationships while mitigating incompatibility between policy elements in the formulation of policy portfolios (Gunningham, Grabosky, \& Sinclair, 1998). Evidence from the drive for renewable energy and energy efficiency as a consequence of climate change and energy security concerns in the last two decade, for example, has shown that internally conflicting elements of policy mixes often elicit contradictory responses from those who are the targets of a program (Del Rio, Silvosa, \& Gomez, 2011; Boonekamp, 2006). This finding is common in many sectors where using both regulation and voluntary compliance measures in the same program 
at the same time undermined the realization of an intended program objective. While some programs can contain duplicative elements and the redundancy or resiliency inherent in them may actually help to ensure that the stated policy goals are achieved, in most cases this is not the result (Grabosky, 1995; Braathen, 2005; Braathen, 2007). Rather, as Hou and Brewer (2011) have noted, programs composed of tools that complement or supplement each other-for example, the use of command and control regulation to prevent undesirable behaviour while simultaneously providing financial incentives to encourage desirable behaviourwill normally achieve more effective policy responses.

\subsection{Balancing Equity, Efficiency, Economy and Environmental Concerns}

A second concern centers less on policy tools and their calibrations and more on program 'settings' or the operationalization of specific program objectives. Numerous case studies of programs, including social policy experience in Australia and United States, have suggested that attaining four general principles in program design at the program-measure interface is critical for program effectiveness: namely achieving "equity, efficiency, economy and environment" in program design (Stanton \& Herscovitch, 2013).

In the context of programs such as those involving progressive taxation, social security benefits, health insurance and retirement incomes, for example, equity is understood to have both a proportional (based on different resource endowments of policy targets) and equal (equal treatment of targets with similar endowments) component and a superior program design takes both aspects into account. For example, proposals for national disability insurance programs in Australia involved a setting of 'proportionality' or unequal treatment of policy targets based on different degrees of disabilities. However it also included an equity component in fostering equal treatment of the same disability across the nation (Stanton \& Herscovitch, 2013). Addressing 'efficiency' as part of a policy program also often takes the shape of meeting larger economic goals while also attaining environmental goals such as sustained growth. Returning to the Conservation Reserve Program (CRP) example cited above, one of the main critiques of the scheme was that once the contracts were signed, farmers were locked in to contracts without any scope for regular inflation adjustments. Designing inflation adjustment mechanisms into the CRP could address this shortcoming in the program's efficiency and enhance its environmental effectiveness.

The principle of 'economy' relates to matching the cost of program initiatives and elements to budgetary and personnel resources and balancing these two aspects. But as Justen, Schippl, Lenz, \& Fleischer (2014) and Justen, Fearnley, Givoni, \& Macmillen (2014) note, participation is a key component in policy and program design, not just for legitimation purposes, but because it can bring new information to the design process which formal analyses can miss. Meeting the need for participatory and inclusive collaboration in policy program design can be attained by managing the coexistence of demand-side and supply-side policies and their constituent policy actors (Daugbjerg \& Sonderskov, 2012). This is especially the case in programs pertaining to the deployment of new technologies such as renewable energy and energy efficiency which require the coordinated participation of both producers and consumers. Along the same vein, encouraging collaborative ties between different types of policy actors can make programs more effective by strengthening knowledge linkages and fostering innovation.

Several design techniques exist which can help promote effective program designs meeting these goals and their combination. As Sovacool (2012) noted in his assessment of ten renewable energy programs in developing countries, mutually supportive combinations can be encouraged while others are discouraged or changed on a pilot or experimental basis. That is, "effective programs typically begin with pilot programs or with feasibility assessments before installing systems and scaling up to larger production or distribution volumes" (p. 9159). Such pilot programs need to be carefully protected from political pressure to evaluate them prematurely, causing adoption of program elements that subsequently prove problematic or rejection of those with latent value, a problem recognized early on in the literature on program evaluation (Weiss, 1970).

\section{Summary: Towards Effective Program Design}

Policy design is an activity conducted by a range of policy actors at different levels of policy-making in the hope of improving policy-making and policy outcomes through the accurate anticipation of the consequences of government actions and the articulation of specific courses of action to be followed to achieve different levels of policy goals and ambitions. In a program design perspective this is to be accomplished by improving assessments of both the theoretical effectiveness as well as the feasibility of policy alternatives at both the policy-program level and the program-measures interface.

That is, each "policy" or program is a complex 'regime' or arrangement of abstract, operationalized and on-the-ground ends and means-related content which exists in a specific governance setting and which change over time. In contrast to an older tradition of program design and evaluation which tended to treat programs in isolation from the larger policy context, the discussion here has located program design firmly within the context of designing complete policy pack- 
ages. In this perspective the central concerns in the design of programs are related to answering questions about how mixes of policy components are constructed, which methods yield superior results in developing these mixes and what is the likely result of their (re)design.

Contemporary design discussions at the policyprogram level center on the articulation of principles such as "goodness of fit" in policy formulation, governance and steering, and the 'degrees of freedom' which formulators or designers have in carrying out their work both over space and over time. These complement and advance notions at the program-mechanism level promoting parsimony in program designs and the need for coherence, consistency and congruence in design relationships and components. At this level efforts have been made to articulate various methods through which designs can meet concerns for equity, efficiency, economy and environmental quality while maximizing complementary interactive effects and minimizing negative or counter-productive ones.

Table 5 summarizes the design principles set out above which can help ensure better policy and program integration through improved linkages between different policy components at the two levels cited above.

What this article has highlighted is that by understanding the nesting of effective program design at the two levels of policy-program and program-measures, program designers can improve or optimize their designs in given historical and institutional contexts. Understanding governance arrangements and how past policy processes have created and modified the elements of existing programs is critical to evaluating the chances of success of policy rules and on-the-ground measures in accomplishing higher level goals and objectives. This realization is helping contemporary program designers in their efforts to deal with policy problems that increasingly demand complex governmental responses.

Table 5. Balancing Policy Elements for Effective Program Design.

\begin{tabular}{|c|c|c|c|c|}
\hline \multicolumn{5}{|l|}{ Policy Content } \\
\hline $\begin{array}{l}\text { High-Level Abstrac- } \\
\text { tion (Policy-Level) }\end{array}$ & $\begin{array}{l}\text { Policy-Program } \\
\text { Linkages }\end{array}$ & $\begin{array}{l}\text { Operationalization } \\
\text { (Program-Level) }\end{array}$ & $\begin{array}{l}\text { Program - Measures } \\
\text { Linkages }\end{array}$ & $\begin{array}{l}\text { On-the-Ground } \\
\text { Specification } \\
\text { (Measures-Level)) }\end{array}$ \\
\hline $\begin{array}{l}\text { GOALS } \\
\text { What ideas govern pol- } \\
\text { icy development? } \\
\text { LOGIC } \\
\text { What norms guide im- } \\
\text { plementation prefer- } \\
\text { ences? }\end{array}$ & $\begin{array}{l}\text { Goodness of Fit with } \\
\text { - Governance styles } \\
\text { (legal, corporate, mar- } \\
\text { ket or network); } \\
\text { - Existing state capac- } \\
\text { ities and social capabil- } \\
\text { ities } \\
\text { - Multi-level policy- } \\
\text { making } \\
\text { Degrees of Freedom } \\
\text { - Working within con- } \\
\text { straints and existing } \\
\text { layers of policy com- } \\
\text { ponent mixes } \\
\text { - Accounting for tem- } \\
\text { porality and historical } \\
\text { arrangements of poli- } \\
\text { cies }\end{array}$ & $\begin{array}{l}\text { OBJECTIVES } \\
\text { What does the policy } \\
\text { formally aim to ad- } \\
\text { dress? } \\
\text { MECHANISMS } \\
\text { What are the specific } \\
\text { types of policy instru- } \\
\text { ments or elements are } \\
\text { how are they utilized? }\end{array}$ & $\begin{array}{l}\text { Maximizing Comple- } \\
\text { mentary Effects } \\
\text { - Assessing interac- } \\
\text { tions between multiple } \\
\text { policy components } \\
\text { - Reducing internally } \\
\text { conflicting elements } \\
\text { and attaining coher- } \\
\text { ence, consistency and } \\
\text { congruence between } \\
\text { program elements and } \\
\text { measures } \\
\text { Balancing the '4 Es' in } \\
\text { policy settings } \\
\text { - Equity (both propor- } \\
\text { tionality and equality) } \\
\text { - Efficiency (alignment } \\
\text { with economic goals } \\
\text { such as employment } \\
\text { and growth) } \\
\text { - Economy (managing } \\
\text { budgetary costs) } \\
\text { - Environmental Con- } \\
\text { cerns (maintaining sus- } \\
\text { tainability of programs) }\end{array}$ & $\begin{array}{l}\text { SETTINGS } \\
\text { What are the specific } \\
\text { aims of policy? } \\
\text { CALIBRATIONS } \\
\text { What are the specific } \\
\text { ways for using the in- } \\
\text { strument? }\end{array}$ \\
\hline
\end{tabular}




\section{Conflict of Interests}

The authors declare no conflict of interests.

\section{References}

Arts, B., Leroy, P, \& van Tatenhove, J. (2006). Political Modernisation and Policy Arrangements: A Framework for Understanding Environmental Policy Change. Public Organization Review, 2006, 6(2), 93-106.

Barnett, C. K. and Shore, B. (2009), Reinventing Program Design: Challenges in Leading Sustainable Institutional Change. Leadership \& Organization, 30(1), 16-35.

Ben-Zadok, E. (2013). Policy Change through Policy Design: Florida Concurrency, 1985-2010. Planning Practice and Research, 28(5), 589-611.

Bobrow, D. B., \& Dryzek, J. S. (1987). Policy Analysis by Design. Pittsburgh: University of Pittsburgh Press.

Bobrow, D. B. (2006). Policy Design: Ubiquitous, Necessary and Difficult. In B. G. Peters \& J. Pierre (Eds.), Handbook of Public Policy. New York: SAGE.

Bode, I. (2006). Disorganized Welfare Mixes: Voluntary Agencies and New Governance Regimes in Western Europe. Journal of European Social Policy, 16(4), 346359.

Boonekamp, P. G. M. Actual Interaction Effects between Policy Measures for Energy Efficiency-A Qualitative Matrix Method and Quantitative Simulation Results for Households. Energy, 31(14), 2848-2873.

Braathen, N. A. (2005). Environmental Agreements Used in Combination with Other Policy Instruments. In E. Croci (Ed.), The Handbook of Environmental Voluntary Agreements (Volume 43, pp. 335-364). Dordrecht: Springer.

Braathen, N. A. (2007). Instrument Mixes for Environmental Policy: How Many Stones Should Be Used to Kill a Bird? International Review of Environmental and Resource Economics, 1(2), 185-235.

Briassoulis, H. (2005). Analysis of Policy Integration: Conceptual and Methodological Considerations. In $\mathrm{H}$. Briassoulis (Ed.), Policy Integration for Complex Environmental Problems: The Example of Mediterranean Desertification. Aldershot: Ashgate.

Christensen, T., Laegreid, P., \& Wise, L. R. (2002). Transforming Administrative Policy. Public Administration, 80(1), 153-178.

Considine, M., \& Lewis, J. M. (2003). Bureaucracy, Network, or Enterprise? Comparing Models of Governance in Australia, Britain, the Netherlands, and New Zealand. Public Administration Review, 63(2), 131-140.

Daugbjerg, C, \& Sønderskov, K. M. (2012). Environmental Policy Performance Revisited: Designing Effective Policies for Green Markets. Political Studies, 60(2), 399418.

David, P. A. (2005). Path Dependence in Economic Processes: Implications for Policy Analysis in Dynamical System Contexts. In K. Dopfer (Ed.), The Evolutionary
Foundations of Economics (pp. 151-194). Cambridge: Cambridge University Press.

Del Rio, P., \& Howlett, M. P. (2013). Beyond the "Tinbergen Rule" in Policy Design: Matching Tools and Goals in Policy Portfolios. SSRN Scholarly Paper. Rochester, NY: Social Science Research Network. Retrieved April 8, 2013 from http://papers.ssrn.com/abstract $=2247238$

Del Rio, P., Silvosa, A. C., \& Gomez, G. I. (2011). Policies and Design Elements for the Repowering of Wind Farms: A Qualitative Analysis of Different Options. Energy Policy, 39(4), 1897-1908.

Doern, G. B., \& Phidd, R. W. (1983). Canadian Public Policy: Ideas, Structure, Process. Toronto: Methuen.

Doern, G. B., \& Wilson, V. S. (Eds.) (1974). Issues in Canadian Public Policy. Toronto: Macmillan.

Dorst, K. (2011). The Core of 'design Thinking' and Its Application. Design Studies, 32(6), 521-532.

Freeman, G. P. (1985). National Styles and Policy Sectors: Explaining Structured Variation. Journal of Public Policy, 5(4), 467-496.

Grabosky, P. (1995). Counterproductive Regulation. International Journal of the Sociology of Law, 23(1995), 347-369.

Gunningham, N., Grabosky, P., \& Sinclair, D. (1998). Smart Regulation: Designing Environmental Policy. Oxford: Clarendon Press.

Guy, K., Boekholt, P., Cunningham, P., Hofer, R., Nauwelaers, C., Rammer, C. (2008) Designing Policy Mixes: Enhancing Innovation System Performance and $R \& D$ Investment Levels. Final Report. Brussels: European Commission.

Hacker, J. S. (2005). Policy Drift: The Hidden Politics of US Welfare State Retrenchment. In W. Streek \& K. Thelen (Eds.), Beyond Continuity: Institutional Change in Advanced Political Economies. Oxford: Oxford University Press.

Hall, P. A. (1993). Policy Paradigms, Social Learning and the State: The Case of Economic Policy Making in Britain. Comparative Politics, 25(3), 275-296.

Hou, Y., \& Brewer, G. (2010). Substitution and Supplementation between Co-Functional Policy Instruments: Evidence from State Budget Stabilization Practices. Public Administration Review, 70(6), 914-924.

Howlett, M. (2011). Designing Public Policies: Principles and Instruments. New York: Routledge.

Howlett, M., \& Cashore, B. (2007). Re-Visiting the New Orthodoxy of Policy Dynamics: The Dependent Variable and Re-Aggregation Problems in the Study of Policy Change. Canadian Political Science Review, 1(2), 50-62.

Howlett, M., \& Cashore, B. (2009). The Dependent Variable Problem in the Study of Policy Change: Understanding Policy Change as a Methodological Problem. Journal of Comparative Policy Analysis: Research and Practice, 11(1), 33-46.

Howlett, M., \& Rayner, J. (2007). Design Principles for Policy Mixes: Cohesion and Coherence in 'New Governance Arrangements'. Policy and Society, 26(4), 1-18. 
Howlett, M., \& Rayner, J. (2013). Patching vs Packaging in Policy Formulation: Assessing Policy Portfolio Design. Politics and Governance, 1(2), 170-182.

Howlett, M., \& Lejano, R. P. (2013). Tales from the Crypt The Rise and Fall (and Rebirth?) of Policy Design. Administration \& Society, 45(3), 357-381.

Howlett, M., \& Migone, A. (2011). Charles Lindblom Is Alive and Well and Living in Punctuated Equilibrium Land. Policy and Society, 30(1), 53-62.

Howlett, M., Mukherjee, I., \& Woo, J. J. (2014). The New Design Orientation in Policy Formulation Research: From Tools to Toolkits in Policy Instrument Studies. Policy and Politics, forthcoming.

Howlett, M., \& del Rio, P. (2014). The Parameters of Policy Portfolios: Verticality and Horizontality in Design Spaces and Their Consequences for Policy Mix Formulation. Environment and Planning, forthcoming.

Jordan, A., Wurzel, R. K. W., \& Zito, A. (2005). The Rise of 'New Policy Instruments in Comparative Perspective: Has Governance Eclipsed Government? Political Studies, 53(3), 477-496.

Justen, A., Schippl, J., Lenz, B., \& Fleischer, T. (2014). Assessment of Policies and Detection of Unintended Effects: Guiding Principles for the Consideration of Methods and Tools in Policy-Packaging. Transportation Research Part A: Policy and Practice, 60, 19-30.

Justen, A., Fearnley, N., Givoni, M., \& Macmillen, J. (2014). A Process for Designing Policy Packaging: Ideals and Realities. Transportation Research Part A: Policy and Practice, 60, 9-18.

Kiss, B., \& Neij, L. (2011). The Importance of Learning When Supporting Emergent Technologies for Energy efficiency-A Case Study on Policy Intervention for Learning for the Development of Energy Efficient Windows in Sweden. Energy Policy, 39(10), 6514-6524.

Lindblom, C. E. (1959). The Science of Muddling Through. Public Administration Review, 19(2), 79-88.

Majone, G. (1989). Evidence, Argument and Persuasion in the Policy Process. New Haven: Yale University Press.

Meijers, E., \& Stead, D. (2004). Policy Integration: What Does It Mean and How Can It Be Achieved? A MultiDisciplinary Review. In 2004 Berlin Conference on the Human Dimensions of Global Environmental Change: Greening of Policies-Interlinkages and Policy Integration, Berlin, Germany.

Meltsner, A. (1972). Political Feasibility and Policy Analysis. Public Administration Review, 32(6), 859-867.

Ostrom, E. (2011). Background on the Institutional Analysis and Development Framework. Policy Studies Journal, 39(1), 7-27.
Ostrom, E., \& Basurto, X. (2011). Crafting Analytical Tools to Study Institutional Change. Journal of Institutional Economics, 7(3), 317-343.

Pierson, P. (2000). Increasing Returns, Path Dependence, and the Study of Politics. American Political Science Review, 94(2), 251-267.

Rayner, J., \& Howlett, M. (2009). Implementing Integrated Land Management in Western Canada: Policy Reform and the Resilience of Clientelism. Journal of Natural Resources Policy Research, 1(4), 321-334.

Richardson, J., Gustafsson, G., \& Jordan, G. (1982). The Concept of Policy Style. In J. J. Richardson (Ed.), Policy Styles in Western Europe (pp. 1-16). London: George Allen and Unwin.

Sovacool, B. K. (2012). Design Principles for Renewable Energy Programs in Developing Countries. Energy and Environmental Science, 2012(5), 9157-9162.

Stanton, D., \& Herscovitch, A. (2013). Social Policy and Program: From Principles to Design. SSRN Scholarly Paper. Rochester, NY: Social Science Research Network. Retrieved April 1, 2013 from http://papers. ssrn.com/abstract $=2258899$

Taeihagh, A., Givoni, M., \& Bañares-Alcántara, R. (2013). Which Policy First? A Network-Centric Approach for the Analysis and Ranking of Policy Measures. Environment and Planning B: Planning and Design, 40(4), 595-616.

Thelen, K. (2003). How Institutions Evolve: Insights from Comparative Historical Analysis. In J. Mahoney \& D. Rueschemeyer (Eds.), Comparative Historical Analysis in the Social Sciences (pp. 208-240). Cambridge: Cambridge University Press.

Tinbergen, J. (1952). On the Theory of Economic Policy. Amsterdam: North-Holland Pub. Co.

USDA (2013). USDA Issues Conservation Reserve Program Rental Payments, Direct Payments and ACRE Payments. USDA FSA News Release, 21/10/2013. Washington: United States Department of Agriculture.

Van der Heijden, J. (2011). Institutional Layering: A Review of the Use of the Concept. Politics, 31(1), 9-18.

Weiss, C. (1970). The Politicization of Evaluation Research. Journal of Social Issues, 26(4), 57-68.

Woodside, K. (1986). Policy Instruments and the Study of Public Policy. Canadian Journal of Political Science, 19(4), 775-793.

Wunder, S. (2007). The Efficiency of Payments for Environmental Services in Tropical Conservation. Conservation Biology, 21(1), 48-58. 
About the Authors

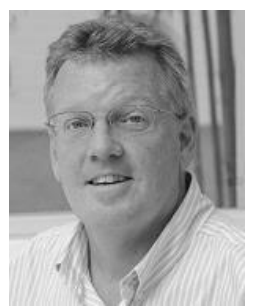

\section{Dr. Michael Howlett}

Michael Howlett is Burnaby Mountain Chair in the Department of Political Science at Simon Fraser University and Yong Pung How Chair Professor in the Lee Kuan Yew School of Public Policy at the National University of Singapore. He specializes in public policy analysis, political economy, and resource and environmental policy. His most recent books are Canadian Public Policy (2013) and The Routledge Handbook of Public Policy (2013).

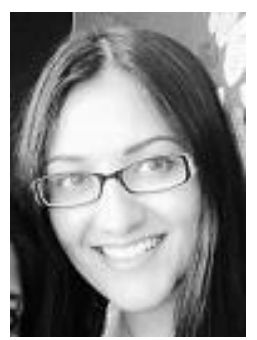

\section{Dr. Ishani Mukherjee}

Ishani Mukherjee is Postdoctoral Fellow at the LKY School of Public Policy, National University of Singapore. She received her PhD in Public Policy from NUS, with a concentration on Environmental Policy. Her research interests combine policy design and policy formulation, with a thematic focus on environmental sustainability, renewable energy and energy efficiency, particularly in Southeast Asia. She has worked previously at the World Bank's Energy practice in Washington, DC, and obtained her BSC (hon) and MSc (hon) in Natural Resources and Environmental Economics from Cornell University.

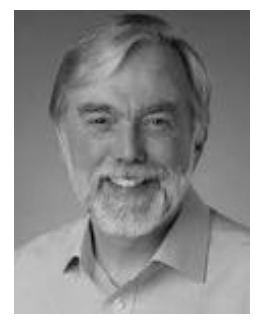

\section{Dr. Jeremy Rayner}

Jeremy Rayner is Centennial Research Chair in the Johnson-Shoyama Graduate School of Public Policy at the University of Saskatchewan. His main areas of specialization in public policy include theories of the policy process (especially policy learning and policy change), policy analysis, governance, resource policy, energy policy and environmental policy. His research currently focuses on governance arrangements for complex policy problems, especially at the intersection of forests, climate change and energy. 